\title{
RITUAL BUDAYA MANDI SAFAR DI DESA TANJUNG PUNAK PULAU RUPAT KABUPATEN BENGKALIS PROVINSI RIAU
}

\author{
Muhammad Ashsubli \\ Sekolah Tinggi Ilmu Ekonomi Syariah Bengkalis, Indonesia \\ ashbi.riau@gmail.com
}

\begin{abstract}
This research aims to show up the local islamic society tradition named ritual mandi safar which get focus from various community of islam itself. Ritual mandi safar represents one of local area ancestor heritage assumed can refuse misfortunes (accident, disaster and disease epidemic). However as the local tradition which is related to islam, it generate pros and contra among the society that support and also refuse it. Relating to that reason, this research aims tofind the meaning of symbol and function of ritual mandi safar for the society that support it. How far their understanding to this rittral and the adtantages for their daily life and also the role of local government to remain this tradition.
\end{abstract}

Keywords : Ritual Mandi Safar, Tradition, Islamic Law

Abstrak. Penelitian ini bertujuan untuk menampilkan tradisi masyarakat Islam lokal yang dikenal dengan nama ritual mandi safar yang mendapatkan fokus dari berbagai komunitas Islam itu sendiri. Ritual mandi safar merupakan salah satu warisan leluhur yang dianggap dapat menolak kemalangan (kecelakaan, bencana dan wabah penyakit). Namun sebagai tradisi lokal yang terkait dengan Islam, itu menghasilkan pro dan kontra di antara masyarakat yang mendukung dan juga menolaknya. Berkaitan dengan alasan itu, penelitian ini bertujuan untuk mengetahui makna simbol dan fungsi mandi mandi Ritual bagi masyarakat yang mendukungnya. Seberapa jauh pemahaman mereka terhadap rittral dan kecakapan ini untuk kehidupan sehari-hari mereka dan juga peran pemerintah daerah untuk mempertahankan tradisi ini.

Kata Kunci: Ritual Mandi Safar, Tradisi, Hukum Islam 


\section{Pendahuluan}

Budaya mempunyai makna yang penting bagi suatu masyarakat. Budaya timbul karena manusia dan interaksi sesama manusia. Salah satu budaya yang berkembang di Indonesia adalah kegiatan pada bulan Safar.

Ritual mandi safar adalah suatu upaya (laku) spiritual ke arah pendekatan diri kepada Tuhan yang dilakukan oleh sebagian masyarakat muslim di beberapa wilayah di Indonesia, di antaranya di beberapa wilayah di Nusa Tenggara Barat, Sulawesi, Kepulauan Riau, Maluku, Kalimantan, termasuk di salah satu wilayah di daerah Riau, tepatnya di Desa Tanjung Punak Pulau Rupat, Kabupaten Bengkalis, Provinsi Riau.

Ritual rutin yang di selenggarakan setiap bulan Safar tersebut dihadiri dan diikuti oleh ratusan bahkan ribuan warga masyarakat, laki-laki maupun perempuan, orang tua maupun orang muda yang datang dari desa-desa sekitar maupun dari daerah lainnya.

Menurut hasil wawancara dengan salah seorang pengurus Lembaga Adat Melayu Rupat Utara, (Pak Dollah), upacara mandi safar ini dimulai sejak tahun 1950. Tradisi ini dibawa dari pesisir pantai di Malaysia.

Masyarakat Rupat Utara sering membaur dengan masyarakat Malaysia karena asalnya kedua kelompok masyarakat ini adalah satu. Namun Pak Dollah menuturkan bahwa mandi safar telah hadir disana sejak tahun 1920-an. Hanya saja mandi safar dilaksanakan di rumah masing-masing, bukan di tempat terbuka.

Ada beberapa perbedaan dalam proses pelaksanaannya, mereka percaya bahwa ritual mandi safar dapat mencegah atau bahkan menghilangkan segala macam kesialan, wabah penyakit

1 Moeslim Abdurrahman, Islam sebagai Kritik Sosial. (Jakarta: Penerbit Erlangga, 2003), h. 155. menular, bencana atau musibah yang akan atau telah datang, khususnya pada bulan Safar.

Hal ini tentunya di motivasi oleh sebuah kepercayaan di kalangan masyarakat luas, bahwa Allah akan menurunkan dua belas ribu macam ujian atau cobaan kepada umat manusia pada bulan Safar, tepatnya pada hari Rabu minggu terakhir bulan Safar.

Terkait dengan eksistensi ritual mandi safar ini tentu menimbulkan pro dan kontra di kalangan masyarakat itu sendiri. Di satu sisi ada yang menganggapnya sebagai tindakan bid'ah yang tidak boleh dilakukan karena bertentangan dengan ajaran Islam yang melarang adanya takhayul dan khurafal serta mengandung unsur syirik, sedangkan di satu sisi lainnya adayang berpendapat bahwa ritual mandi safar hanyalah sekedar tradisi leluhur yang bernafaskan Islam yang perlu dipelihara kelestariannya, tentunya dengan mengedepankan modifikasi-modifikasi Islami dan membuang unsur-unsur mistisisme. Atau dengan bahasa lain, meminjam istilah Moeslim Abdurrahaman, "mengislamkan tradisi atau budaya lokal". ${ }^{1}$

Pro dan kontra tersebut tentunya berawal dari dua kubu yang selalu berseberangan bahkan menimbulkan gesekan internal umat Islam antara gerakan ortodoksi Islam dan priburnisasi Islam dalarn melihat Islam vis to vis tradisi lokal.

Gerakan ortodoksi Islam atau purifikasi Islam dipakai oleh mereka yang berusaha memisahkan secara tegas nana yang hak dan mana yang batil, menurut versi mereka tanpa ada toleransi sedikitpun, dan menempatkan ajaran Islam sebagai ajaran formal yang perlu diterapkan apa adanya sesuai 
dengan pemahaman dan tafsir mereka atas Alquran dan hadis.

Pendekatan ini dipakai ketika ajaran "tauhid Islam" versi mereka berhadapan dengan paham "mitologi" yang menurut mereka berbau "khurffit dan takhayul". Sedangkan pendekatan pribumisasi Islam atau akomodatifreformatif adalah pendekatan yang lebih menangkap ideal moral Islam daripada aspek legal formalnya. Islam dipahami secara kontekstual, lentur, respektif, dan apresiatif terhadap budaya lokal. ${ }^{2}$

Tampaknya, bila melihat eksistensi ritual-ritual yang ada di beberapa wilayah Indonesia, mnasyarakat lebih cenderung menerima pola akomodatifreformatif atau pribumisasi Islam ketimbang pola purifikasi Islam.

Hal itu cukup beralasan karena setiap orang lahir dari lingkungan "adat" dan kulturalnya masing-masing. Kebudayaan setempat, di mana orang itu dibesarkan, sangat berpengaruh terhadap inkulturasi dan akulturasi keberagamaan seseorang. Oleh karena itu, Moeslim Abdurrahman mengatakan,

"Sulit diterima jika ada kenyataan bahwa seseorang bisa beragama secara "murni," tanpa dibentuk oleh kulturnya. Kecuali mungkin seorang nabi atau rasul sungguhan yang boleh mengatakan bahwa ia telah mendapatkan wahyu dari Tuhan. Namun selebihnya, jika orang biasa saja, pengetahuan dan cara bagaimana mengungkapkan keberagaman, tidak lain hal itu diperoleh karena diajarkan oleh orang tuanya, oleh guru dan kiyaikiyai, bahkan oleh kebiasaankebiasaan yang diwarisi begitu saja dari tradisi di sekitarnya."3

Dalam kenyataan seperti itu, agama tidak lain menjadi identik dengan tradisi. Atau sebuah ekspresi budaya

2 Simuh, "Interaksi Islam dalam Budaya Jawa" dalam Muhammadiyah dalam Kritik. tentang keyakinan orang terhadap sesuatu Yang Suci, tentang ungkapan keimanan terhadap Yang Maha Kuasa. Jikalau hubungan agama dan tradisi ditempatkan sebagai wujud interpretasi sejarah dan kebudayaan, maka semua domain agama adalah kreativitas manusia yang sifatnya sangat relatif.

Artinya bahwa, kebenaran agama yang diyakini setiap orang sebagai yang "benar", pada dasarnya hal itu sebatas yang bisa ditafsirkan dan diekspresikan oleh manusia yang relatif atas "kebenaran" Tuhan yang absolut. Dengan demikian, apa pun bentuk yang dilakukan oleh sikap manusia untuk mempertahankan, memperbaharui atau memurnikan tradisi agama, tetap saja harus dipandang sebagai pergulatan dalam dinamika sejarah umat beragama itu sendiri.

Terlepas dari pro dan kontra tersebut di atas, ritual mandi safar masih tetap eksis diselenggarakan oleh masyarakat desa Tanjung Punak, tepatnya di Pantai Tanjung Lapin, Rupat Utara Kabupaten Bengkalis, Provinsi Riau. Bahkan, yang cukup menarik untuk diperhatikan bahwa ritual tersebut dimotori oleh Pemerintah Daerah, dan didukung pula oleh Gubernur Riau Ir. H. Arsyanjulaindi Rahman. Akhirnya pemerintah daerah setempat telah menetapkan bahwa ritual mandi safar adalah salah satu aset kearifan lokal sekaligus objek wisata tahunan yang diharapkan dapat menarik wisatawan domestik maupun manca negara.

Bertolak dari alasan-alasan itu, pelaksanaan ritual mandi safar di Desa Tanjung Punak, tepatnya di Pantai Tanjung Lapin, Rupat Utara Desa Kabupaten Bengkalis Provinsi Riau tentu merupakan fenomena sosial keagamaan dan budaya yang cukup menarik dan unik. Di satu sisi dianggap

(Surakarta: Muhammaddiyah University Press, 2002), h. 149.

3 Moeslim Abdurrahman,......h. 153 
mendatangkan manfaat bagi sebagian pihak, namun di sisi lain memunculkan pergesekan internal umat Islam antara yang pro dan yang kontra, khususnya masyarakat sekitar.

Berdasarkan fenomena tersebut, maka eksistensi ritual mandi safar menarik untuk dikaji lebih jauh sebagai kajian etnografi. Penelitian ini akan terlihat bagaimana dan apa sebenarnya urgensi dari mandi safar, dilihat dari segi agama, politik, budaya dan sosial.

\section{Rumusan Masalah dan Tujuan Penelitian}

Rumusan masalah dalam penelitian ini adalah 1) Bagaimana proses pelaksanaan dan apa maknamakna simbol dalam ritual mandi safar? 2) Bagaimana pemahaman masyarakat sekitar terhadap makna dan fungsi penyelenggaraan ritual mandi safar dalam kehidupan sehari-hari? 3) Bagaimana peranan pemerintah daerah setempat dalam melestarikan ritual mandi safar sebagai objek wisata?

Adapun tujuan penelitian ini antara lain untuk; l) Memahami makna simbol dalam suatu ritual keagamaan. 2) Mengeksplorasi sejauh mana pemahaman masyarakat terhadap hakikat dan fungsi ritual mandi safar dalam kehidupan sehari-hari. 3) Bagaimana peranan pemerintah Kabupaten setempat melestarikan ritual mandi safar sebagai salah satu objek wisata.

\section{Kerangka Teori}

Untuk membantu dalam proses penelitian ini, peneliti menggunakan beberapa teori untuk memaknakan realitas dan data yang tengah dihadapi dan dikaji agar mampu menganalisis dengan penuh kritik. Dengan beberapa teori ini diharapkan dapat membangun atau memodifikasi teori berdasarkan pada data yang telah dikumpulkan dan dianalisis. Beberapa karangka teori ini mencakup: 1) Teori induk Parsons mengenai sistern sosial, teori sibernika, teori aksi dan teori fungsional. ${ }^{4}$ 2) Teori kewenangan (authoritative) dari Weber. Pemakaian teori-teori di atas dengan pertimbangan bahwa satu dengan lainnya saling melengkapi atau menunjang

\section{Metode Penelitian}

Penelitian ini adalah penelitian lapangan (field research) dengan metode kualitatif sebagai pendekatannya, yaitu peranan peneliti sebagai instrumen utama dalam proses penelitian. Seorang peneliti berusaha mendeskripsikan dan memahami fenomena sosial atau masyarakat sebagaimana masyarakat itu sendiri mempersepsikan diri mereka (to learn from the peoples) atau bersifat emik (emic foctors).

Atas dasar pendekatan di atas, maka beberapa langkah yang dilakukan antara lain sebagai berikut pertama, melakukan observasi partisipasi atau pengalaman terlibat secara sungguhsungguh di lapangan dengan mengamati beberapa kegiatan upacara Ritual mandi safar pada konteks yang sebenarnya (truly natural context) dan bukan yang dibuat-buat (artficial context). Kedua, memahami makna, nilai dari kegiatan itu, sesuai dengan pandangan atau pemahaman para pelakunya sendiri seperti pemimpin agama, dan umat bersangkutan. Ketiga, berusaha mengkorelasikan beberapa temuan yang ada. Langkah terakhir atau keempat, setelah data dapat dipahami dengan mengkategorisasikan serta mengidentifikasikan Ritual mandi safar berbagai macam karakteristik yang ada, maka berusaha mengembangkan 
hipotesis, konsep, dan teori-teorinya. Dengan cara seperti ini, maka proses penelitian dilakukan secara berulangulang, karena tahap pengumpulan dan analisisnya dilakukan secara simultan terus menerus sampai ditemukan konklusi pemahaman yang mantap sesuai dengan apayang ada di lapangan.

Penemuan dan pengumpulan data dalam penelitian ini dilakukan dengan cara observasi partispasi atau peneliti bersikap sebagai participant as observer, berusaha masuk (getting in) menjadi partisipan dari masyarakat subjek penelitian, sehingga dapat mendapatkan kepercayaan sebagai bagiannya. Akan tetapi, karena waktu penyelenggaraan Ritual mandi safar ini hanya sekali dilakukan dalam setahun, maka untuk penelitian ini dibantu dengan penggunakan beberapa sumber dokumentasi berupa VCD dan foto-foto yang tersimpan di beberapa lembaga maupun perseorangan. Setelah data terkait dengan prosesi ritual mandi safar, data primer juga diperoleh melalui wawancara dengan informan dan responden secara mendalam (in-depth). Para informan terdiri atas tokoh agama atau pemimpin agama dan masyarakat setempat.

Pengalaman wawancara secara mendalam, dengan menggunakan pedoman wawancara dan teknik wawancara untuk setiap pertemuan dengan para informan dan responden. Untuk merangkum hasil refleksi yang diharapkan sebagaimana realitas yang ada (emics) terhadap semua pengalaman individual, maka banyak dilakukan dengan menggali infiormasi dari informan kunci (key informant) yang banyak memiliki pengetahuan luas dan

5 N. Muhadjir, Metodologi Penelitian Kualitatif: Telaah Positivistik, Rasionalistik, dan Phenomenologik. (Yogyakarta: Rake Sarasin, 1989), h. 134-135. mendalam, dalam hal ini dipilih subyek penelitian yang kaya akan informasi. ${ }^{5}$

Di samping data yang bersifat primer berada di lapangan, teknik pengumpulan data yang lebih bersifat skunder didapatkan dari teknik dokumentasi berupa studi pustaka, arsip, dan berbagai macam laporan yang ada di perpustakaan, maupun beberapa kantor instansi setempat berhubungan dengan penelitian yang dilakukan. Pemeriksaan keabsahan data dilakukan dengan memperhatikan empat kriteria, yaitu kredibilitas, transferabilitas, dependabilitas, dan konfirmatibilitas. ${ }^{6}$

Agar mampu menganalisis dengan penuh kritik situasi yang tengah dikaji, untuk kemudian melakukan berbagai abstraksi mengenai apa yang sesungguhnya tengah terjadi di lapangan, maka diperlukan pegangan teori- Sebab itu beberapa teori yang telah dikemukakan, semata-mata tidak untuk diuji, tetapi dimaksudkan untuk memaknakan realitas dan data yang ada.

\section{Hakikat Ritual Mandi safar}

Ritual merupakan suatu bentuk atau perayaan (celebratian) yang berhubungan dengan beberpa kepercayaan atau agama dengan ditandai oleh sifat khusus, yang menimbulkan rasa hormat yang luhur dalam arti merupakan suatu pengalaman yang suci. ${ }^{7}$

Mandi safar adalah mandi pada bulan Safar guna menghilangkan bala' yang diturunkan Allah untuk semua umat manusia di dunia ini dari papan Lauh Mahfuzh. Syaukani al-Karim, budayawan Bengkalis mengatakan bahwa pada mulanya safar diartikan sebagai kosong. Pada masa lampau, kaum-kaum awal dan masyarakat

${ }^{6}$ Lincoln, Y.S and Guba, E. G. Naturalistic Inquiry. (California: SAGE Publications, 1984).

7 Thomas. F. O'Dea, Sosiologi Agama: Suatu Pengenalan Awal. Terj. Yasogama. (Jakarta: PT Raja Grafindo Persada, 1995), h.5-36. 
jahiliyah di Jazirah Arab pra Islam, menjadikan bulan Safar sebagai bulan peperangan, mereka meninggalkan rumah dalam keadaan kosong. Mungkin saja dalam hal ini, safar dipandang sebagai bulan duka cita dan air mata. ${ }^{8}$

Dalam tafsir lain, safar juga disebut bulan tiupan angin. Dari sudut pandang musim, dipandang kurang menguntungkan dan karenanya sejumlah aktivitas tidak dapat dilakukan secara maksimal. Barangkali dari kegagalan ini kebanyakan masyarakat menganggap bulan Safar sebagai bulan penuh bala.

Safar, dapat pula diartikan sebagai kuning. Di beberapa kalangan masyarakat, kuning dianggap sebagai lambang penyakit. Ada pula yang menganggap bahwa safar merupakan nama penyakit. Masyarakat Arab Jahiliyah meyakini bahwa safar adalah penyakit yang bersarang di perut akibat adanya ulat kecil yang berbahaya. Konon, Nabi Ayyub a.s. terkena penyakit kulit juga pada bulan Safar ini.

Menurut H. Abdurrahman bin $\mathrm{H}$. Abdul Aziz dalam kitab Jawahir, Allah menurunkan 320.000 bala pada setiap tahun dan sebagian besar turun pada hari Rabu terakhir bulan Safar. Hal inilah yang menjadi dasar pemilihan hari Rabu terakhir sebagai waktu untuk ritual tolak bala. ${ }^{9}$ Menurut M. Natsir pada bulan Safar Nabi Nuh mendapat bahaya banjir bandang dan nabi Ayyub terkena sakit kulit. Mengambil hikmah dari kisah para nabi tersebut, maka masyarakat percaya bahwa bulan Safar penuh dengan bahaya.

Masyarakat Pulau Rupat menamakan hari pelaksanaan mandi safar ini 'Rabu Capuk' yang berarti Rabu yang selalu meninggalkan bekas buruk. Di wilayah Rupat Utara khususnya, halhal yang dilarang pada hari Rabu Capuk adalah tidak boleh bekerja menangkap ikan, menebang kayu walaupun sekedar memetik daun atau mematahkan ranting. Sebab menurut kepercayaan setempat, orang yang terkena luka kena kapak, ditimpa kayu, terjatuh dan lain sebagainya akan meninggalkan bekas yang buruk.

Masyarakat Melayu menganut ajaran Islam, sehingga masyarakat melayu menyisipkan ajaran keislaman dalam pelaksanaan adat kebudayaan. Hal inilah yang menyebabkan munculnya akulturasi Islam dan budaya masyarakat Melayu, khususnya pada upacara mandi safar.

Pengalaman itu mencakup segala sesuatu yang dibuat atau dipergunakan oleh manusia untuk menyatakan hubungannya dengan yang "Tertinggi", dan hubungan atau perjumpaan itu sesuatu yang sifatnya biasa atau umum, tetapi sesuatu yang bersifat istimewa, sehingga manusia membuat suatu cara yang pantas guna melaksanakan pertemuan itu, maka muncullah beberapa bentuk ritual agama seperti ibadat yang bertujuan untuk memohon maupun ritual mandi safar menyembah kepada Dzat Tertinggi.

Dalam ritual agama dipandang dari bentuknya secara lahiriyah merupakan hiasan atau semacam alat saja, tetapi pada intinya yang lebih hakiki adalah "pengungkapan iman". Oleh karena itu, upacara atau ritual agama diselenggarakan pada beberapa tempat, dan waktu yang khusus, perbuatan yang luar biasa, dan berbagai peralatan ritus lain yang bersifat sakral. Dengan demikian ritual keagamaan dalam rangka pertemuan atau menjalin hubungan seorang individu dengan Yang Maha Tinggi, baik untuk memohon maupun memuja, terkadang dilakukan dengan berbagai macam cara yang dikaitkan dengan moment-moment tertentu. Misalnya saja, dalam ajaran 
Islam saja, terdapat beberapa ritual yang dikaitkan dengan fenomena alam, seperti salat istisqa (salat untuk minta hujan) dan salat gerhana matahari atau bulan (salat kusuf dan khusuf. Yang pertama adalah ritual yang tujuannya adalah untuk minta diturunkan hujan pada saat musim kemarau, sedangkan yang kedua adalah salat yang dilakukan pada saat terjadi gerhana matahari atau bulan dengan tujuan hanya untuk mendekatkan diri kepada Allah dalam rangka untuk mengungkapkan rasa keta'dziman dengan kekuasaan Allah yang tiada duanya.

Beberapa ritual tersebut merupakan ritual yang memang benarbenar ada aturannya di dalam sunnah Rasulullah saw. di mana aturan itu tentunya mendapatkan perintah atau persetujuan dari Allah Swt. Namun, di kalangan umat Islam sendiri dan masyarakat pada umumnya, khususnya di Indonesia, masih banyak terdapat ritual-ritual yang merupakan hasil karya dan cipta manusia yang tujuannya tidak lain untuk mendekatkan diri kepada Zat Yang Kuasa maupun untuk memohon sesuatu, atau hanya sekedar wujud dari bentuk ungkapan syukur atas apa yang telah diberikan-Nya kepada umat manusia.

Ritual atau upacara itu memiliki berbagai macam bentuk, tergantung dengan fenornena alam yang dihadapinya. Di Jawa misalnya, terdapat ritual sedekah laut, ritual grebeg mulud, ritual bersih desa, kenduri atau selamatan dan lain-lain. Di wilayah Jambi juga banyak ditemukan berbagai macam ritual, di antaranya ritual cuci kampung, ritual menjelang tanam maupun panen padi, kenduri atau selamatan, termasuk juga ritual mandi safar dan lain-lain.

Dengan banyaknya macam ritual tersebut, tidak jarang muncul anggapan di kalangan masyarakat umum bahwa ritual tersebut merupakan ritual keagamaan, khususnya agama Islam, yang harus dijalankan dan bahkan menganggap bahwa ritual-ritual tersebut ada dasar hukumnya dan termasuk ajaran dari agama Islam itu sendiri. Inilah yang kemudian menjadi pemicu munculnya kelompok yang pro dan kontra di kalangan umat Islam. Kelompok yang pro tentunya menganggap ritual tersebut merupakan ritual yang diajarkan oleh salafus shalih dan harus dilaksanakan secara turun temurun dan bila ditinggalkan maka ada perasaan yang kurang pas di hati. Sedangkan kelompok yang kontra beranggapan bahwa ritual-ritual tersebut tidak memiliki dasar hukum dari Alquran maupun sunnah, oleh karenanya masuk dalam kategori bid'ah dhalalah (perbuatan yang menyesatkan) yang bisa mengantarkan kepada kemusyrikan.

Salah satu ritual yang hingga saat ini menjadi kontroversi di kalangan masyarakat Islam khususnya adalah ritual mandi safar. Ritual mandi safar adalah ritual mandi yang dilaksanakan pada hari Rabu terakhir bulan Safar setiap tahun Hijriyah, yang diawali dengan menulis tujuh ayat Alquran yang berawal "Salamun", kemudian dimasukkan ke dalam air yang akan dipergunakan untuk mandi. Mandi safar diyakini sebagian masyarakat sebagai salah satu ritual yang dapat menghindarkan manusia dari berbagai rnacam bala, bencana, dan penyakit serta menyelamatkan manusia dari fitnah (siksa) Dajjal. ${ }^{10}$

Sebagian umat Islam di Indonesia menganggap Mandi safar sebagai salah satu ritual yang bersumber dari ajaran agama (Alquran dan Hadis Rasululah saw.) sebagai sumber utama pelaksanaan semua syari'at dan ritual

${ }^{10}$ Arsyad, wawancara: 1 Agustus 2015. 
Islam. Namun, menurut keterangan KH. M. As'ad Arsyad sebenarnya secara eksplisit anjuran Mandi safar tersebut tidaklah ditemukan dalam dua sumber utama tersebut. Salah satu sumber yang dipegang selama ini adalah ungkapan Syeikh Syarfuddin dalam kitabnya "Ta'liqah" yang menjelaskan bahwa ritual mandi safar pada malam Rabu terakhir bulan Safar, Allah Swt. menurunkan dua belas ribu macam bala (bencana berupa bencana alam maupun wabah penyakit atau cobaan) dari lauhul rnahfudz ke langit dunia. Maka untuk rnenghindarkan diri dari berbagai macam bala tersebut, beliau menuliskan tujuh ayat dari Alquran kemudian diminum dengan niat untuk memperoleh kebaikan dan barokah. Demikian yang dikutip dari kitab "Taj alMulk" hal-7l, pasal Doa Mandi Pada Bulan Safar.

Sumber lain mengatakan bahwa praktik yang serupa dengan mandi safar dikisahkan oleh seorang ulama besar bernama al-Syeikh Muhammad bin Atwi al-Maliki al-Hasani, dalam kitabnya Abwab al-Faraj hal. 63 pasal Pengobatan dengan Ayat Syifa,yang mengisahkan bahwa al-lmam al-Syeikh Abu al-Qashim al-Qusyairi Rahimahullah, anaknya sakit keras sampai-sampai ia hampir berputus asa melihat kondisi anaknya, kemudian dalam tidur ia bermimpi bertemu dengan Nabi, lalu ia mengadukan kondisi anaknya tersebut. Kemudian Nabi berkata; 'Apakah engkau tidak mengetahui ayat-ayat syifa yang ada dalam Alquran?" Kemudian imam alQusyairi segera mencari ayat-ayat yang dimaksud Rasulullah tersebut. Dan ditemukanlah enam ayat dalam Alquran yang mengandung kata syifa, yaitu yang terdapat dalam surat at al-Taubah (14), Yunus (57), al-Nahl (69), al-Isra (82), dan al-Syu'ara (80). Kemudian al-

11 M. As'ad Arsyad, Acara Ritual mandi safar dan Syukuran Nelayan. (Jambi. Dinas
Qursyairi menulis ayat-ayat tersebut di atas kertas dan memasukkannya ke dalam air dan disuguhkan kepada anaknya untuk diminum sebagai penawar, maka kemudian sembuhlah anak tersebut dari penyakitnya. ${ }^{11}$

Adapun ketujuh ayat yang disebut di dalam kitab Tajul Muluk terdapat dalam surat Yasin (58), ashShafat (79), ash-Shafat (109), ash-shafat (120), ash-Shafat (130), az-zumat (73), dan al-Qadar (5).12 Berbeda dengan Surabaya, ritual mandi safar juga dilakukan oleh sebagian masyarakatnya, namun yang ditulis bukanlah enam ayat syifa atau tujuh ayat yang diawali dengan lafadz salamun, melainkan menuliskan hurf-huruf rajah-rajah pada sehelai kertas atau daun kemudian diletakkan ke dalam bak mandi atau gentong air minum atau sumur pada waktu-waktu tertentu di bulan Safar. Kemudian air tersebut digunakan untuk mandi atau air minum.

Bagi rnasyarakat Desa Tanjung Punak Pulau Rupat Utara, Mandi safar menjadi momen penting dalam setahun sekali, guna memupuk tali persaudaraan "ukhuwwah wathaniyah" (persaudaraan sebangsa dan setanah air) tanpa membedakan suku, ras, dan agama, semua bersama-sama, mengikuti dan melaksanakan ritual tersebut. Menurut M. As'ad Arsyad, pelestarian Mandi safar bukan pengkultusan budaya yang bermuara pada adanya keyakinan bahwa apabila tidak melaksanakan atau mengikuti tradisi tersebut akan tertimpa bala, bencana, dan tidak selamat. Sebab, bala dan bencana, serta penyakit tidak akan menimpa manusia, melainkan telah menjadi ketetapan Sang Pencipta alam semesta. Keselamatan dan kebahagiaan pun demikian, adalah atas ketentuan Allah Swt. Di samping ikhtiar dan usaha sebagaimana layaknya dalam

Kebudayaan dan Pariwisata Kab. Tanjabtim, 2005), h. 9. 
kehidupan yang benar, bukan dengan Mandi safar atau ritual-ritual lain yang tidak sesuai dengan tuntutan Allah dan Rasul-Nya. Allah Swt., ini pulalah yang menjadi alasan bagi mereka yang tidak melaksanakan atau bahkan menentang tradisi mandi safar tersebut.

Mandi safar dalam pandangan mayoritas masyarakat Desa Tanjung Punak, Pulau Rupat Utara adalah tradisi yang patut untuk dilestarikan dan menjadi khas serta wujud kebersamaan masyarakat Desa yang pelaksanaannya bersifat fleksibel, dapat saja dikemas dengan berbagai acara dan kegiatan lain selama tidak merubah esensi atau tiga hal utama dalam kegiatan mandi safar yakni: pertama, menulis atau menghafal tujuh ayat Alquran yang diawali dengan lafadz salamun, kedua, berniat untuk mandi karena Allah Swt., ketiga, mandi itu sendiri. Bila dilihat dari masa diselenggarakannya ritual mandi safar secara berjamaah, hingga sekarang sudah tiga puluh lirna tahunan. Namun, ritual ini menjadi event daerah sejak turun-temurun. Dan sampai saat ini ritual tersebut terus akan diselenggarakan sebagai event daerah yang bekerjasama dengan pemerintah daerah setempat, Pemkab Bengkalis Provinsi Riau, dan menjadikannya sebagai salah satu objek wisata tahunan.

Hal ini dilakukan karena beberapa motivasi, pertama, sebagai sarana mempererat ukhuwah islamiyah dan ukhuwah insaniyah (persaudaraan karena hubungan keagamaan maupun karena sosial kemasyarakatn), kedua; membuka akses ekonomi dengan menjadikannya sebagai objek pariwisata, ketiga, mempercepat pembangunan daerah.

\section{Proses Persiapan dan Pelaksanaan}

Ritual mandi safar sebagai suatu perayaan, pesta, perjamuan benar-benar dianggap sebagai sesuatu perhelatan besar daerah yang membutuhkan persiapan secara matang. Bagi masyarakat Desa Tanjung Punak, Pulau Rupat Utara, upacara ini tidak hanya membutuhkan biaya saja tetapi tenaga dan pikiran dari semua komponen masyarakat desa. Meskipun perayaan itu dianggap rutin, tetapi setiap tahun diadakan persiapan jauh sebelumnya secara khusus, yang kemungkinan dapat terjadi saran atau usul-usul usaha peningkatan atau pengembangan. Baik dari segi sarana dan prasarana maupun muatan acara ritual mandi safar yang kaitkan dengan syukuran nelayan.

Prosesi upacara mandi safar dimulai dari pagi hari. Setelah subuh, masyarakat menyiapkan peralatan yang dibutuhkan.Selanjutnya disiapkan sehelai daunatau selembar kertas persegi (rajah) yang kemudian diserahkan pada tetua kampung yang dianggap memiliki ilmu agama cukup. Rajah tersebut ditulisi ayat-ayat menggunakan benda-benda keras seperti lidi yang dibuat menyerupai pensil dengan ujung dilancipkan, atau tinta yang mudah luncur.

Prosesi mandi safar dimulai dengan zikir bersama lalu dilakukan arakarakan diiringi kompang beserta 8 pasang anak yang merupakan perwakilan masing-masing desa di Kecamatan Rupat Utara menuju sumur tua. Sumur tua ini tak jauh dari Pantai Tanjung Lapin. Konon, menurut seorang tokoh masyarakat bernama Ismail Umar, sumur tua itu disebut sumur lapin yang dinilai memiliki keistimewaan tersendiri dan dipercaya sebagai sumur keramat yang tidak pernah kering meskipun kemarau panjang. Selain itu, airnya tidak terasa asin walaupun berada di tepi laut. ${ }^{13}$

Dolah, selaku pemandu mengawali prosesi dengan berdiri sembari

\footnotetext{
13 mediacenter.riau.go.id
} 
membacakan doa-doa, kemudian menulis ayat di secarik kertas lalu dimasukkan ke dalam 'pasu'. Pasu adalah sebuah tempayan keramik yang dihias dengan janur berbentuk miniatur gunung, burung dan lainnya. Dipinggiran tempayan berjalin rapi mayang pinang berajut membentuk lingkaran memenuhi pinggir tempayan. Setelah itu, 8 pasang anak-anak dipersilahkan untuk duduk berbaris di depan 8 buah pasu yang telah dihias dengan pucuk dan mayang kelapa. Air yang sudah dimasukkan kertas tersebut disebut 'wafa").14

Satu persatu tetua adat, pemuka agama dan pemerintah setempat menepuk tepung tawari anak-anak itu, kemudian air wafa' disiramkan ke tubuh mereka menggunakan centong dari tempurung kelapa. Setelah selesai, warga dipersilahkan mengambil air wafa'. Saat itulah warga saling berlari dan berebut mengambil air doa tersebut. Ada yang membasuh muka, ada yang membasuh rambut, dan ada pula yang membawa botol air mineral kosong untuk diisi air wafa'. Bahkan beberapa masyarakat ada yang menjadikan rajah yang direndam tadi untuk digantung di atas pintu rumah dengan tujuan agar bala bencana dan penyakit tidak masuk ke dalam rumah.

Setelah itu masyarakat melakukan kenduri di sumur (riaugreen.com). Mereka menikmati ketupat lemak dan makanan-manakan yang mereka bawa bersama-sama. Selesai kenduri itu, masyarakat pergi mandi ke laut secara bersama-sama, setelah itu barulah dibilas dengan air sumur lapin yang sudah dibacakan doa tadi. Menurut $\mathrm{H}$. Abdullah, Ketua LAM Riau Kecamatan Rupat Utara, hal ini dipercaya mampu membersihkan segala bala bencana dari tubuh seseorang. ${ }^{15}$ Suasana menjadi

\footnotetext{
14 goriau.com
}

semarak, canda tawa dan segala kebersamaan mengisi prosesi tersebut.

Sekarang acara ini sudah dikelola dan ditata oleh Dinas Kebudayaan Pariwisata Pemuda dan Olahraga Kabupaten Bengkalis. Lebih dari itu, karena ketertarikan Gubernur Riau pada budaya ini, pemerintah daerah bermaksud akan menjadikan budaya mandi safar di Rupat Utara ini sebagai event nasional. Hal ini guna mendukung visi Riau 2020 yang bertemakan Riau, the homeland of Melayu.

Ritual mandi safar, sebenarnya bisa dilakukan secara sendiri sendiri dengan beberapa tahapan; pertama, menulis tujuh ayat Alquran yang diawali dengan lafadz salamun. Ayat-ayat tersebut ditulis di atas daun atau kertas dengan menggunakan tinta yang mudah terhapus atau menghafalkan ayat-ayat tersebut (bagi yang menghafalnya tidak perlu menulisnya lagl). Kedua, memasukkan tulisan (ayat) tersebut ke dalam baskom atau tempat air (bak mandi, drurn, gentong, sumur dan sebagainya) yang akan dipergunakan untuk mandi. Ketiga, berniat untuk mandi dengan lafadz sebagai berikut; "aku berniat untuk mandi karena Allah Taala". Keempat, pelaksanaan mandi bisa saja dengan menggunakan seember air di rumah atau di sungai.

Cara pelaksanaan yang lain adalah dengan menulis ketujuh ayat tersebut dan memasukkannya ke dalam gelas lalu meminumnya, seperti yang dijelaskan oleh Seikh Syarfuddin, dengan niat untuk memperoleh kebaikan dan berkah (tabarru'an). Namun, apabila ritual itu akan dilakukan bersama-sama sebagaimana yang dilakukan di pantai Desa Tanjung Punak, maka tahap persiapan akan dilakukan oleh panitia yang telah ditunjuk. Masyarakat pada umumnya cukup

15 Wawancara H. Abdullah Ketua LAM Riau Kec. Rupat Utara 
datang di tepi pantai pada saat acara ritual mandi safar dilakukan. Adapun tahap pelaksanaan dilakukan secara bertahap, pertama, mengambil daun mangga yang digunakan untuk menulis tujuh ayat yang diawali dengan lafadz salamun dengan tinta mudah luntur. Tujuh lernbar daun mangga itu dilakukan pada malam hari oleh orang yang Ritual mandi safar biasanya ditunjuk oleh seorang kiayi. Setelah ditulis, tujuh lembar daun tersebut diletakkan di atas nampan yang berlapis kain putih. Namun, bagi orang yang sudah hafal tidak perlu menuliskannya di atas tujuh lembar daun tersebut, tapi cukup membacanya pada saat hendak melakukan mandi. Kedua, meletakkan menara yang sudah diberi telur-telur matang di dekat pantai di depan panggung utama. Ketiga, sambutansambutan dari beberapa pejabat daerah dan ditutup dengan sambutan dari ketua panitia yang menjelaskan kepada masyarakat bagaimana teknis dan urgensi dari ritual mandi safar. Keempat, proses mandi bersama-sama di tepi pantai yang diawali dengan niat dan kemudian mencelupkan tujuh lembar daun mangga yang sudah tertulis tujuh ayat keselamatan baru kemudian merendamkan diri ke dalam air yang dipimpin oleh pemimpin ritual rnandi Safar. Kelima, setelah selesai mandi, para pemimpin daerah setempat maupun tokoh adat naik di atas rakit yang sudah dibawa ke permukaan air di pantai untuk membagi-bagikan telur matang yang sudah disiapkan sebelumnya. Setelah itu satu sama lain saling bersalaman untuk bermaafmaafan.

Setelah prosesi ritual mandi safar ini selesai dilaksanakan maka dilanjutkan dengan kegiatan-kegiatan kemasyarakatan lainnya, seperti lomba layang-layang, perahu hias, memancing dan lain sebagainya.

\section{Makna Simbol-Simbol Adat}

Adapun kelengkapan yang diadakan dalam pelaksanaan ritual mandi safar, seperti payung pengayom pemimpin jalannya ritual dan rakit dengan menara di atasnya yang dipikul oleh banyak orang, bukan merupakan keharusan, terlebih berupa sesajen atau persembahan, melainkan sekedar merupakan simbol-simbol semata yang memiliki makna-makna tertentu sebagai berikut. 16

Menara Tunggal bermakna bahwa Tuhan yang berhak disembah hanya satu. Jumlah satu juga menunjukkan lambang kebersamaan dan persatuan masyarakat Desa Tanjung Punak bersatu dalam membangun dan bersatu dalarn mewujudkan segala citacita Bangsa dan Negara Republik Indonesia. Rakit dan Pondasi Menara dibuat dalam bentuk segi empat, dalam bahasa Bugis disebut Sulapa Eppa atau Eappa Sulapa yang merniliki makna sebagai "empat unsur penciptaan manusia", yaitu; tanah, api, angin, dan air dengan ciri dan sifatnya rnasing-masing. Tanah sifatnya duduk, api sifatnya berdiri, angin sifatnya ruku, dan air sifatnya bersujud. Ini menunjukkan bahwa manusia diciptakan tiada lain kecuali hanya untuk mengabdi kepada Allah Sang Pencipta, sesuai dengan tuntunan Alquran dan hadis Rasulullah. Rakit lnenara terbuat dari kayu, nibung dan nipah. Nibung dan Nipah merupakan khas Melayu, yang telah drjadikan sebagai slogan daerah "Sepucuk Nipah Serumpun Nibung".

Nibung dan Nipah dari dulunya dij adikan sebagai rakit untuk menuju satu daerah melintasi laut dan sungai, setibanya di suatu tempat yang dituju maka Nibung dan Nipah tadi diangkut ke 
daratan untuk dijadikan sebuah rumah. Nibung sebagai tongkat dan lantai sementara daun Nipah dijadikan atap dan dinding. Nibung dan Nipah merupakan bahan utama untuk membangun tempat tinggal bernaung dan berteduh bagi sebagian masyarakat di Bengkalis. Sosok seorang pemimpin di depan menara yang membawa doa yang telah ditulis di atas tujuh lernbar daun yang akan dipakai dalam mandi safar, menunjukkan keharusan adanya seorang pernirnpin dalam suatu masyarakat yang bisa menjadi pengayom, pelindung, dan pengambil keputusan dalam setiap masalah yang dihadapi dengan seadil-adilnya, serta menjadi penyejuk bagi seluruh masyarakat dan rakyat yang dipimpinnya. Tujuh lembar daun berisikan doa untuk mandi safar.

Melalui ritual mandi safar diharapkan segala sesuatu berjalan dengan baik dan sukses. Payung yang menaungi pernimpin adalah simbol kesetiaan rakyat kepada pemimpin yang adil dan bijaksana dalam memimpin dan mengayomi rakyatnya. Pembawa rakit dan menara adalah perwakilan dan seluruh masyarakat Desa Tanjung Punak.

Hal ini menunjukkan bahwa ritual mandi safar konsep utama dalam pembangunan adalah kebersamaan dan kegotongroyongan, serta kemauan untuk berbuat dan berkorban Masyarakat yang hadir dalarn acara ritual adat tidak diperbolehkan untuk mandi terlebih dahulu sebelum tokoh yang dipercaya untuk membawa doa yang berada di depan rakit menara melakukannya. Hal ini menunjukkan keharusan setiap anggota masyarakat untuk taat dan patuh kepada pemimpin selama kepemimpinannya berada dalam rel kebenaran dan keadilan, sebagaimana yang pernah dituturkan oleh Rasulullah saw. bahwa tidak ada ketaatan dalam dosa dan maksiat. Sebenarnya, di Desa Tanjung Punak yang merupakan desa bahari dan terletak di pesisir timur Sumatera, tepatnya di Kecamatan Rupat Utara Kabupaten Bengkalis Provinsi Riau, berhadapan langsung dengan negara Malaysia, sebelumnya sudah ada upacara y ang bernama Maccera' Kampong atau Maddoassalama' Kampong. Upacara ini dilakukan setiap tahun sejak dibukanya desa ini.

KH. Muharnmad Said Magwie menjelaskan bahwa tradisi Mandi safar adalah upaya doa untuk keselamatan yang diwujudkan dalam praktek tradisional, seperti minum dan mandi dengan air yang mengandung doa. Doa mandi shalar yang berisikan tujuh ayat Alquran yang kesemuanya berawal "salamun", bertujuan untuk memohon keselamatan. Doa mandi safar sebagian ada yang ditulis sebagian ada yang langsung dibaca, bahkan menghafalnya. Membaca ayat Alquran adalah bertujuan untuk memohon syafaat, memohon dengan penuh harapan dan optimisme. Dalam bahasa agama dikenal dengan istilah "tafa'ul". Mandi dan minum dengan ayat hanyalah perantara,namun yang menyembuhkan adalah Allah Swt. ${ }^{17}$

Prof. Dr. K.H. Sulaiman Abdullah memberikan komentar bahwa menurut syara sesuatu yang dilakukan oleh orang banyak dan mengandung maslahat namun tidak bertentangan dengan ajaran agama maka hal tersebut boleh dilakukan dan dilestarikan. Pada prinsipnya agama (Islam) tidak memberantas tradisi, selama tradisi tersebut tidak merusak aqidah umat. Agama Islam menegaskan bahwa jika suatu tradisi mengarah padaperusakan akidah maka harus ditinggalkan. Hal ini sejalan dengan nash artinya:

${ }^{17}$ Arsyad, h. 8. 
"sesungguhnya Allah menghalalkan yang baik-baik dan mengharamkan yang buruk-buruk."

Mandi safar-seperti halnya tradisi-tradisi lain yang berkembang di masyarakat-meskipun terkesan merupakan tradisi yang bernuansa agama, namun pada dasarnya tradisi tersebut bukanlah bagian dari agama. Sebab, Islam melalui Alquran dan Hadis tidak pernah memerintahkan untuk melaksanakan mandi safar. Oleh karena itu, dalam upacara mandi safar yang perlu dikedepankan adalah aspek "tradisi dan budayanya" bukan aspek ritual keagamaannya. Sebab jika mandi safar dianggap sebagai ritual keagamaan yang ditandai misalnya dengan niat mandi safar, menuliskan ayat-ayat tertentu pada sehelai kertas atau daun dan mandi, maka hal tersebut dikhawatirkan akan melahirkan pemahaman di kalangan masyarakat bahwa mandi safar atau ayat tersebut yang menyembuhkan, menyelamatkan, dan menghindarkan orang dari segala macam bala dan bencana.

Pemahaman seperti ini adalah pemahaman yang berbau syirik, sebab pada hakikatnyayang dapat menyembuhkan, menyelamatkan, dan menghindarkan orang dari bala dan bencana hanyalah Allah semata." Mengenai terdapatnya ayat syifa (penyembuh) dalam Alquran, pada dasarnya merupakan petunjuk untuk rnencarai syifa' (penyembuh/penawar). Ayat-ayat dalam Alquran pada hakikatnya hanyalah berfungsi sebagai perantara bukan tujuan (penyembuh). Allah Swt. tidak membeda-bedakan ayat satu dan lainnya, semua ayat dalam Alquran merupakan hudan (petunjuk) bagi manusia dalam kehidupan di dunia. Dengan demikian, mandi safar sebagai tradisi dapat saja dilaksanakan dan dilestarikan sepanjang tidak dianggap sebagai ritual keagamaan yang ditandai dengan praktik-praktik niat mandi safar dan menuliskan sejurnlah ayat pada sehelai daun dan mengalirkannya. Mandi pada umumnya suatu yang dianjurkan dalam agama sebab mandi adalah salah satu cara untuk membersihkan badan dengan harapan terhindar dari kotoran dan penyakit, namun harus didasari dengan niat semata kepada Allah. Tradisi mandi safar sebagai wahana untuk meningkatkan ukhuwah Ritual mandi safar wathoniyah dan ukhuwah insaniyah pada sisi lain, tidak bertentangan dan sangat dianjurkan oleh agama. ${ }^{18}$

Sedangkan untuk membedakan kategori bidah atau tidak itu terlihat pada niat yang diucapkan. Menurut KH. M. As'ad Arsyad, bahwa niat yang diucapkan adalah "saya niat mandi safar karena Allah Taala', bukan "saya niat mandi safar sunnah karena Allah Taala '. Niat yang kategori pertama, tidak terrnasuk dalam kategori bidah. Bidah di sini adalah mengada-adakan sesuatu ibadah yang tidak ada dasarnya dalam Alquran dan Sunnah tetapi dianggapnya itu sebagai ajaran dari Alquran dan Sunah (agama Islam).

Adapun yang dianggap masuk dalam kategori bidah adalah model niat yang kedua, di mana pada niat itu dicantumkan lafadz "sunnah", yang berarti itu ada dasar hadisnya baik qauliyah maupunfi'liyah, padahal dari penelusuran yang dilakuan bahwa hadis yang menyatakan anjuran melakukan mandi safar tidak ditemukan. Dengan demikian, ritual mandi safar di Desa Teluk Punak tidak termasuk dalam kategori bidah dhalalah (bidah yang menyesatkan). Justru dalam ritual ini memuat unsur pendidikan yang gambarkan melalui simbol-simbol yang digunakan dalam ritual tersebut dan

18 Arsyad, h. 9. 
mencerminkan nilai-nilai keislaman yang cukup tinggi. Oleh karena itu, bisa saja ritual mandi safar ini dianggap sebagai tradisi yang dikemas dengan nilai-nilai keagamaan, khususnya Islam. ${ }^{19}$

\section{Fungsi Ritual Mandi safar}

\section{1) Fungsi Sosial}

Budaya atau tradisi sebagai ciptaan manusia yang muncul dari perasaan dan diwujudkan dalam bentuk simbol yang ekspresif, mempunyai berbagai macam fungsi, salah satu fungsi yang mendasar adalah "fungsi sosial". Dalam hal ini, fungsi sosial dipahami bahwa kehadiran tradisi semata-mata sebagai refleksi penguat atau kesetiakawanan sosial. Selain itu, kedudukan tradisi dalam kehidupan keberagarnaan masyarakat sebenarnya merupakan kesatuan dalam fungsi yang sama. Agama juga dipahami sebagai bagian dunia imajinasi yang sangat penting yang berfungsi sosial. Sejauh mana agama dilihat dari fungsi ini, bagi pengikut teori fungsional, mernandang sebagai hasil dari tiga karakteristik dasar eksistensi manusia hidup bermasyarakat, yaitu manusia hidup dalam "ketidakpastian", kondisi manusia dalam kaitan konflik antara keinginan dan kenyataan ditandai oleh "ketidakberdayaan", dan manusia (masyarakat) berada di tengah-tengah kondisi "kelangkaan".20 Ketiga karakteristik yang bersifat sosial itu akan membawa manusia berhadapan langsung dengan berbagai macam masalah kritis pada "titik kritis" dengan perilaku sehari-hari yang berstruktur. Terkadang terdapat masalah yang yang tak dapat terlampaui atau diatasi oleh pengalaman manusia, dan hanya bisa

${ }^{19}$ KH. M. As'ad Arsyad, hasil wawancara: 11 September 2016. dijawab oleh hal-hal yang bersifat transenden.

Fungsi sosial yang mengandung kebersamaan atau kesetiakawanan dalam ritual mandi safar adalah fungsi dasar yang dijadikan pegangan. Ritual mandi safar sebagai ritual keagamaan dilakukan untuk memperkuat solidaritas kelompok masyarakat dari seluruh etnis maupun agama yang ada di wilayah desa Teluk Punak dan sekitarnya. Pengungkapan tindakan atau sikap-sikap secara bersama dalam ritual, manusia tidak hanya menunjukkan kebersamaan saja, tetapi justru memperkuat sikap-sikap itu. Ritual keagamaan menanamkan sikap ke dalam kesadaran diri yang tinggi yang sangat memperkuat mereka, dan melalui peristiwa itu akan memperkuat komunitas moral. 21

Pengalaman keagamaan dan budaya sebagai salah satu bentuk prilaku manusia dengan berdasarkan norma-norma yang dianut secara bersama, telah diciri sebagai fungsi sosial pemersatu aspirasi manusia yang paling luhur dan indah. Sejumlah besar norma, moralitas sebagi sumber tatanan yang telah dipadu dengan nilai-nilai agama yang mengandung unsur-unsur kebaikan, maupun kebenaran, membuat manusia makin beradab. Manusia yang "buta pemahaman agama' akan mudah bertindak tanpa pertimbangan kemanusiaan, mengarah kepada budaya kekerasan, dan menjadi manusia biadab.

Kehadiran agama yang dikemas dalam nuansa kebudayaan merupakan bagian dari keseluruhan sistem sosial itu sungguh-sungguh mempunyai fungsi manifes atau diharapkan. Ritual Mandi safar Dengan demikian, kesadaran religiusitas atau persoalan agama dan masyarakat tak luput dari pembicaraan kaum fungsionalis yang memandang

20 O'Dea, h. 7-ll

21 Talcot Parsons, The Structure of Social Action. 2nd ed. (New York: McGraw-Hill, 1949) 
bahwa sumbangan agama terhadap kebudayaan berdasarkan arti pentingnya, yaitu sesuatu yang mentransendensikan pengalaman, suatu yang berada di luar dunia empiris.

Berdasarkan pandangan seperti itu, maka fenomena kesadaran religiusitas dalam realitas sosial ini dipahami dengan konsep fungsional dari kerangka teori fungsionalisme struktural. Teori ini memandang bahwa masyarakat sebagai suatu sistem sosial, terdiri dari bagian-bagian yang satu dengan lainnya saling berkaitan dan saling menyatu dalarn keseimbangan. ${ }^{22}$

Dalam hal ini agama termasuk ritual di dalamnya sebagai salah satu bentuk prilaku manusia yang telah terlembaga, adalah bagian dari keseluruhan sistem sosial dan berfungsi bagi masyarakat khususnya sebagai pengintegrasi.

\section{2) Fungsi Politik}

Fenornena proses akulturasi yang terjadi dalam ritual ini adalah adanya hasil tindakan aktif-kreatif atau aksi manusia atau individu sebagai aktor. Untuk memaknakan gejala itu, dipahami dengan teori aksi atau tindakan (action theory) yang dikembangkan oleh Parsons dengan mengikuti karya Weber. ${ }^{23}$

Menurut Parsons dengan mengemukakan konsep voluntarism, yaitu kesukarelaan individu atau aktor melakukan tindakan (volunteering for action) dalam arti menetapkan cara atau alat dari sejumlah alternatif yang tersedia, dalam rangka mencapai tujuan. Aktor dalam hal ini umat (masyarakat), perangkat sampai pemimpin upacara ritual mandi safar, adalah pelaku aktif dan kreatif, serta mempunyai kemampuan menilai dan memilih dari alternatif tindakannya.

22 George Ritzer, Sociology; A Multiple Paradigm Science'. Boston: Allyn and Bacon, Inc. Sanderson, Stephen, K. 1990. Sosiologi Makro:
Walaupun tidak sepenuhnya mempunyai kebebasan total, karena masih dibatasi oleh kondisi, norma, dan nilai-nilai serta situasi penting lainnya, seperti kondisi situasional lingkungan budaya, tradisi, agama, tetapi dibalik itu aktor adalah manusia aktif, kreatif dan evaluatif. Berkaitan dengan tindakan individu atau aksi di atas, aktivitas dan kreativitas kegiatan ritual itu tidak lepas dengan konsep "kekuasaan" atau power dari golongan atau kelompok. Makna kekuasaan atau power dari seorang pemimpin pesantren atau kiai dalam realitas sosial ini, dipahami sebagai tipe power "charismatic domination" dari teori authoritative (kewenangan) yang dikernbangkan Weber, yaitu memberikan legitimasi kekuasaan bagi orang-orang tertentu, dalam hal ini seperti pemimpin agama atau kiai. Seorang kiai sebagai tokoh karismatik mempunyai power dengan bentuk dan sifat khusus yang biasanya dipatuhi oleh umatnya. Struktur power yang berdasarkan berbagai macam hak dari kualitas seorang karisrnatis, sungguh menarik karena dapat melakukan bermacam-macam efek perubahan atau pembaharuan.

Dalam tradisi ritual mandi safar yang diikuti hampir seluruh warga di desa Teluk Punak dan bahkan dari daerah-daerah sekitarnya menunjukkan bahwa pemimpin kharimatik akan diikuti dan dipatuhi oleh masyarakat pada umumnya. Dalam hal ini, kepentingan politik yang dikedepankan adalah kepentingan perubahan dan pembangunan, bukan kekuasaan. Dengan diadakannya ritual mandi safar, desa ini memiliki keuntungan ganda. Pertama, sebagaimana telah disebutkan, ritual mandi safar dapat menyatukan masyarakat dalam satu ikatan sosial tanpa melihat suku, ras, dan agama,

Sebuah Pendekatan krhadap Realitas Sosial. Jakarat: Rajawali Press, 1980) h. 25-30.

23 Ibid, h.52-58 
yaitu kesetiakawanan sosial (ukhuwah insaniyah). Kedua, keuntungan ekonomi, di mana dengan tetap diadakannya ritual mandi safar, desa Teluk Punak sering dikunjungi oleh para petinggi daerah maupun masyarakat pada umumnya. Dengan demikian akan menpromosikan potensi perekonomian daerah setempat yang cukup kaya akan hasil laut.

\section{3) Fungsi Agama}

Dari perspektif aplikatif, hukum Islam terbagi dua; yaitu hukum Islam dalam kaitannya dengan syariat dan yang kedua hukum yang berakar pada wilayah ijtihad. Mandi safar dapat ditinjau dari sisi wilayah ijtihad.

Mandi menurut Islam ada 3 jenis, yaitu mandi wajib, mandi Sunnah dan mandi mubah. Dilihat dari kategorinya, mandi safar tidak tergolong mandi wajib maupun mandi Sunnah, karena tidak ada satu dalil pun yang mengatur tentang mandi safar. Sehingga mandi safar ini dikategorikan mandi mubah, karena tidak ada hal yang menyunahkan atau mewajibkannya. Mandi merupakan cara Islam untuk menjaga kesehatan dan kebersihan.

Mandi safar merupakan kebiasaan yang berawal dari mengamati tradisi daerah lain, kemudian dianggap baik, maka masyarakat mengikutinya. Budaya mandi safar ini memiliki manfaat untuk menjalin ukhuwah wathoniyah, saling bekerja sama, menjaga kekompakan, rasa kekeluargaan, menghilangkan batasan antara sikaya dan si miskin, menghilangkan jarak yang jauh, mendekatkan pejabat dan rakyat. Selain itu mandi safar berpotensi sebagai daerah tujuan pariwisata yang berdampak pada peningkatan ekonomi warga setempat. Melalui kegiatan tersebut, tentu saja menarik minat para

24 Effendi Tenas. Tunjuk Ajar Melayu. (Yogyakarta: Balai Kajian dan Pengembangan Budaya Melayu, 2011). investor dan pemerintah untuk memperbaiki infrastruktur di sana.

Pepatah Melayu mengungkapkan harmonisasi antara adat dan Islam dalam syair " adat bersandi syarak, syarak bersandi kitabullah. Ya kata syarak benar kata adat, adat tumbuh dari syarak, syarak tumbuh dari kitabullah." Selama adat tidak melanggar syariat, maka boleh dikembangkan masyarakat. Itu berarti bahwa segala sesuatu yang ada pada masyarakat melayu wajib mengacu pada Islam dan tidak boleh menyelisihinya. Jika ada hal yang tidak sesuai dengan ajaran Islam maka harus diluruskan. Dengan kata lain budaya melayu tidak dapat dipisahkan dari ajaran Islam. ${ }^{24}$

\section{Kesimpulan}

Ritual mandi safar merupakan tradisi sebagian masyarakat rnuslim, khususnya di Indonesia. Dilihat dari proses dan fungsinya, ritual mandi safar tidak bertentangan dengan ajaran agama Islam, karena tidak ada unsur bid'ah dhalalah. Terkhusus pada niatnya. oleh karena itu, sebagai tradisi yang memiliki nilai-nilai luhur dari segi sosial kemasyarakatan, maka harus tetap dipertahankan. Apalagi tardisi semacam ini dapat meningkatkan pengembangan potensi wilayah, dari segi ekonorni maupun wisata. Dalam rangka pengembangan ilmiah, penelitian ini masih perlu dikembangkan dan diperdalam lagi. 


\section{DAFTAR PUSTAKA}

Abdurrahman, Moeslim. Islam sebagai Kritik Sosial. Jakarta: Penerbit Erlangga, 2003.

Arsyad, M. As'ad. Acara Ritual mandi safar dan Syukuran Nelayan. Jambi. Dinas Kebudayaan dan Pariwisata Kab. Tanjabtim, 2005.

Banton, Michael. Antropological Approaches to the Study of Religion. London: Tavistock Publications, 1973.

Denzim, Norman. K; Yvona S. Lincoln. Handbook Qualitative Research. London:-New Delhi: SAGE Publications, 1994.

Geertz, Clifford. Myth ond Culture. New York: W.W. Norton \& Company, Inc, 1971. 1980. Tafsir Kebudayaan. Yogyakafta: Penerbit Kanisius, 1980.

Lincoln, Y.S and Guba, E. G. Naturalistic Inquiry. California: SAGE Publications, 1984.

Koentjaraningrat, (ed). Metode-Metode $P$ enelitian Masyarakat. Jakarta: PT. Gramedia, I977.

Muhadjir, N. Metodologi Penelitian Kualitatif: Telaah Positivistik, Rasionalistik, dan Phenomenologik. Yogyakarta: Rake Sarasin, 1989.

Moloeng, Lexy. J . Metodologi Penelitian Kualitatif. Bandung: Rosdakarya, 2005.

O'Dea, Thomas. F. Sosiologi Agama: Suatu Pengenalan Awal. Terj. Yasogama. Jakarta: PT Raja Grafindo Persada, 1995.
Parsons, Talcot. The Structure of Social Action. 2nd ed. New York: McGrawHill, 1949.

. The Social System. New York: The Free Press, 1951.

Paton, Michael Quin. Qualitative Evaluationn and Research Methods. Newbuy Park: SAGE Pub, 1990.

Ritzer, George. Sociology; A Multiple Paradigm Science'. Boston: Allyn and Bacon, Inc. Sanderson, Stephen, K. 1990. Sosiologi Makro: Sebuah Pendekatan krhadap Realitas Sosial. Jakarat: Rajawali Press, 1980.

Simuh. "Interaksi Islam dalam Budaya Jawa" dalam Muhammadiyah dalam Kritik. Surakarta: Muhammaddiyah University Press, 2002.

Tenas Effendi. Tunjuk Ajar Melayu. Yogyakarta, Balai Kajian dan Pengembangan Budaya Melayu, 2011.

Internet:

www.google.com

www.riaugreen.com

www.goriau.com

www.riaupos.co 
JURNAL AQLAM -- Journal of Islam and Plurality -- Volume 3, Nomor 1, Juni 2018 